NBER WORKING PAPER SERIES

EXCHANGE RATE REGIMES AND CAPITAL MOBILITY:
HOW MUCH OF THE SWOBODA THESIS SURVIVES?

\author{
Barry Eichengreen \\ Working Paper 14100 \\ http://www.nber.org/papers/w14100 \\ NATIONAL BUREAU OF ECONOMIC RESEARCH \\ 1050 Massachusetts Avenue \\ Cambridge, MA 02138 \\ June 2008
}

Prepared for the conference in honor of Alexander Swoboda, Geneva, 30 May 2008. Thanks to Inci Otker-Robe and Harald Anderson for data and to Raul Razo-Garcia for help with the calculations. Sections 2 and 3 are an update and extension of Eichengreen and Razo-Garcia (2006). I thank Raul Razo-Garcia for his input into the larger project of which this paper is part. The views expressed herein are those of the author(s) and do not necessarily reflect the views of the National Bureau of Economic Research.

NBER working papers are circulated for discussion and comment purposes. They have not been peerreviewed or been subject to the review by the NBER Board of Directors that accompanies official NBER publications.

(C) 2008 by Barry Eichengreen. All rights reserved. Short sections of text, not to exceed two paragraphs, may be quoted without explicit permission provided that full credit, including $\odot$ notice, is given to the source. 
Exchange Rate Regimes and Capital Mobility: How Much of the Swoboda Thesis Survives?

Barry Eichengreen

NBER Working Paper No. 14100

June 2008

JEL No. F31

\begin{abstract}
$\underline{\text { ABSTRACT }}$
Alexander Swoboda is one of the originators of the bipolar view that capital mobility creates pressure for countries to abandon intermediate exchange rate arrangements in favor of greater flexibility and harder pegs. This paper takes another look at the evidence for this hypothesis using two popular de facto classifications of exchange rate regimes. That evidence supports the bipolar view for the advanced countries, the sample for which it was originally developed, but not obviously for emerging markets and other developing countries. One interpretation of the contrast is that there is a tendency to move away from intermediate regimes in the course of economic and financial development, implying that emerging markets and other developing countries will eventually abandon intermediate regimes as well. Another interpretation is that the advanced countries have been faster to abandon soft pegs because they have been faster to develop attractive alternatives, notably Europe's monetary union. In this view, other countries are unlikely to abandon soft pegs because of the absence of the distinctive political conditions that have made the European alternative feasible. A final interpretation is that the advanced countries have been able to abandon soft peg because of their success in substituting inflation targeting for exchange rate targeting as the anchor for monetary policy. The paper presents some evidence for this view, which suggests the feasibility of further movement by emerging markets and developing countries in the direct of greater exchange rate flexibility.
\end{abstract}

\author{
Barry Eichengreen \\ Department of Economics \\ University of California \\ 549 Evans Hall 3880 \\ Berkeley, CA 94720-3880 \\ and NBER \\ eichengr@econ.Berkeley.edu
}




\title{
Exchange Rate Regimes and Capital Mobility: How Much of the Swoboda Thesis Survives? ${ }^{1}$
}

\author{
Barry Eichengreen \\ University of California, Berkeley \\ May 2008
}

\section{Introduction}

Alexander Swoboda is recognized for many important contributions to exchange rate economics. One of the less known is the fact that he is the father (grandfather? godfather?) of the bipolar view - that is, of the idea that capital mobility creates pressure for countries to abandon intermediate exchange rate arrangements in favor of greater flexibility and harder pegs. Looking back on his contributions to this literature (Swoboda 1986, Genberg and Swoboda 1987a, b), it is hard to know whether to group him with the hawks or doves. ${ }^{2}$ The hawks argue that international capital mobility fatally undermines the viability of intermediate regimes. It makes it more difficult to maintain both monetary independence and an exchange rate target. Insofar as monetary independence has value, the result is adoption of a more flexible exchange rate. And insofar as the stability offered by an exchange rate target has value, the result is a tendency to seek monetary unification with like-minded partners.

While the doves acknowledge that that capital mobility complicates the operation of intermediate arrangements, they resist the conclusion that it creates irresistible pressure to move to the poles. As in other economic settings where agents trade off two objectives,

\footnotetext{
${ }^{1}$ Prepared for the conference in honor of Alexander Swoboda, Geneva, 30 May 2008. Thanks to Inci Otker-Robe and Harald Anderson for data and to Raul Razo-Garcia for help with the calculations. Sections 2 and 3 are an update and extension of Eichengreen and Razo-Garcia (2006). I thank Raul Razo-Garcia for his input into the larger project of which this paper is part.

${ }^{2}$ A number of others have laid claim to this theory or discovered it independently, such as Crockett (1994) and Eichengreen (1994). But Swoboda came first.
} 
an interior solution may be optimal. In the present context this means striving for a degree of monetary independence that is less than complete and a degree of exchange rate stability that is less than perfect. This interior solution will be characterized by managed flexibility. The exchange rate will have to be more flexible than when capital mobility is absent, in which case it is possible to have monetary independence without compromising currency stability, but free flexibility is not required. The middle may have to be defined more liberally - in addition to pegged but adjustable rates and narrow bands it now must include managed floats and wide bands. Subject to this caveat, however, capital mobility does not imply the need to abandon intermediate regimes. It is unlikely that one more paper will produce a consensus on these contested issues, which have occupied Alexander Swoboda in the course of a long and productive career. But if nothing else, another look at the data will help the participants in this debate to refine their priors.

\section{Another Look at the Evolution of Exchange Rate Regimes}

In this section I take another look at the evolution of practice with respect to exchange rate regimes, using two popular de facto classifications. The first one is produced by the staff at the International Monetary Fund. As described by Bubula and Otker-Robe (2002), this classification combines market exchange rates and other quantitative information with assessments of the nature of the regime drawn by IMF economists in the course of bilateral surveillance. Its advantage is that it is independently constructed; the author cannot be accused of having coded country regimes to his liking. This series has now been updated through 2006. Its disadvantage is that, based as it is in 
part on input from the IMF's country economists, this series is not easily extended. The second classification is that of Reinhart and Roff (2004), who provide a detailed description of their methods. This classification has been updated by the author in collaboration with Raul Razo Garcia. ${ }^{3}$ Somewhat arbitrarily, most of the analysis here is conducted using the Bubula and Otker-Robe calculation. ${ }^{4}$ Statements below refer to this classification except where noted to the contrary.

Table 1 documents the decline in intermediate regimes since 1990. For the full sample of countries, the share of intermediate regimes (fixed pegs to a single currency, fixed pegs to a basket, currencies pegged within horizontal bands, forward looking crawling pegs, forward looking crawling bands, backward looking crawling pegs, backward looking crawling bands and other lightly managed floats) falls from about 70 per cent in 1990 to about 45 percent in 2004. The evacuees move to hard pegs and floats in roughly equal proportions.

Beneath these regularities are contrasts between the advanced countries, emerging markets, and developing countries. ${ }^{5}$ Among the advanced countries, intermediate regimes have essentially disappeared. (The one country still classified as operating a soft peg is Denmark.) This supports the bipolar view for the countries for which it was first

\footnotetext{
${ }^{3}$ There exist still further alternatives, notably those of Ghosh, Gulde and Wolf (2003), Levy-Yeyati and Sturzenegger (2003, 2007) and Shambaugh (2004).

${ }^{4}$ Comparisons suggest that the analysis undertaken here is not particularly sensitive to the measure of de facto exchange rate regime used. This is what we found in Eichengreen and Razo-Garcia (2006). Where it is sensitive is with respect to the choice between measures of de facto and de jure regimes. And the arguments above apply to de facto regimes. The IMF has long published a series for countries' official (self-announced) exchange rate regimes. Alesina and Wagner (2003) provide an analysis of why de jure and de facto regimes might differ.

${ }^{5}$ The definition of advanced countries coincides with the definition of industrial countries in International Financial Statistics. Following Bubula and Otker-Robe (2002), emerging markets are defined as the countries included in the Emerging Market Bond Index Plus (EMBI+), the Morgan Stanley Capital International Index (MSCI), Singapore, Sri Lanka and Hong Kong SAR. Taiwan is excluded from the sample of emerging countries to make the results comparable to Bubula and Otker-Robe (2002). The resulting sample consists of 24 advanced countries, 32 emerging market countries and 126 developing countries.
} 
developed. Within this subgroup, the dominant movement has been toward hard pegs, reflecting monetary unification in Europe.

Although emerging markets have also seen a decline in the prevalence of intermediate arrangements, these regimes still account for more than a third of the relevant subsample (41 per cent in 2006, down from 77 per cent in 1990). Here the majority of the evacuees have moved to floats rather than fixes, reflecting the absence of EMU-like arrangements in other parts of the world. ${ }^{6}$ But it is apparent that the move away from intermediate regimes among these countries has slowed and even reversed in recent years. The same pattern is evident in Table 2 for the Reinhart-Rogoff classification. $^{7}$ There is a secular trend away from intermediate regimes, albeit one that has slowed and even reversed in recent years. ${ }^{8}$

The prevalence of intermediate regimes has again declined among developing countries. Where these regimes accounted for two thirds of the developing country subsample in 1990 (Table 1), they account for a bit more than half today (55 per cent of the total in 2006, down from 64 per cent in 1990). As with emerging markets, the majority of those abandoning the middle have moved to floats rather than hard pegs. How will the constellation of regimes look in 20 years if present trends continue? This question can be answered by using a simple Markov chain model, as in Masson

\footnotetext{
${ }^{6}$ Note that BOR's floats include managed floats but not "tightly managed floats," which are classified as intermediate regimes, consistent with the idea that there really has been an increase in flexibility.

${ }^{7}$ The tabulations here differ very slightly from those in Eichengreen and Razo-Garcia (2006) because new data became available in some cases for earlier years (on, inter alia, black and parallel exchange rates). In other cases, countries are classified as operating de facto pegs and de facto crawling pegs using five year windows, so the updating can in a few instances have implications for prior years.

${ }^{8}$ For what it is worth, the emerging markets classified as having moved to intermediate regimes using the Reinhart-Rogoff procedures strictly are Nigeria in 2004 (managed exchange rate to de facto band), Malaysia (preannounced peg to de facto crawling peg), Philippines(managed to de facto crawling band) and Thailand (freely floating to de facto crawling band) in 2005, and Argentina (managed to de facto crawling band) in 2007.
} 
(2001) and Eichengreen and Razo-Garcia (2006), to estimate the probability of regime transitions. This assumes that the past is a guide to the future and that the probability of being in a regime in the next period depends only on the current regime. ${ }^{9}$ For the sample as a whole (Bubula and Otker-Robe classification), the most persistent state is a hard peg, followed by the intermediate and, last, floating regimes (Table 3). There is no absorbing state and hence no tendency for countries to converge to a single regime or subset of regimes. The last line of the table shows the distribution of regimes if current trends continue for another 20 years. This suggests that in two decades 30 per cent of countries will have pegs, 30 per cent will have floats, and 40 per cent will have intermediate arrangements. Compared to the current constellation, the share of intermediate regimes will have declined further, but only modestly.

The picture looks different when calculations are done separately for advanced countries, emerging markets, and developing economies. Among the advanced countries, intermediate arrangements are the least persistent while hard pegs are an absorbing state. This, of course, is just another way of saying that no country that joined EMU since 1999 has left. ${ }^{10}$ By 2025, the share of floaters is forecast to decline from 40 per cent to 30 per cent of the advanced-country subsample, one imagines through the adoption of the euro by additional countries. ${ }^{11}$

\footnotetext{
${ }^{9}$ Appendix 2 of Eichengreen and Razo-Garcia (2006) describes the derivation of these matrices. Appendix 3 of that paper also presents modified matrices constructed on the basis of estimates of how various covariates affect the likelihood of regime transitions. Those matrices together with assumptions about the evolution of the covariates allow us to relax the assumption that transition probabilities are independent of country characteristics, and they allow us to apply alternative assumptions about how the key characteristics evolve over time.

${ }^{10}$ Something that the author has argued will most likely remain the case (Eichengreen 2007).

${ }^{11}$ Not too much should perhaps be made of this point, which is a function of the fact that a growing number of European countries adopted the euro starting in 1999. Implicit here is the question of whether this tendency for countries to gravitate toward the Euro area could shift into reverse in the future.
} 
Among emerging markets and developing countries, in contrast, hard pegs are the most persistent regime, followed by intermediate arrangements and then floats; note that this is a different pattern than for the advanced countries. ${ }^{12}$ Here there is not strong support for the bipolar view. The Markov chain analysis suggests that the share of emerging markets and developing with floating rates will actually be lower in 2025 than today, reversing the trend in recent decades. This reflects the fact that intermediate arrangements are more persistent than flexible regimes in this subsample. They may be adopted infrequently, but once adopted they persist. Thus, this analysis does not suggest that intermediate regimes will disappear anytime soon outside the OECD.

At the same time, the contrast between the advanced, emerging and developing countries suggests that there is a tendency to move away from intermediate regimes in the course of economic and financial (and political?) development. To the extent that this is true, one can imagine that the phenomenon of the hollow middle will eventually spread from the now-advanced countries to the rest of the world. One interpretation is that economic development, in practice, is associated with financial liberalization and the removal of capital controls, which heighten the fragility of intermediate regimes and prompt movement to the poles. This suggests that if developing countries follow their advanced-country counterparts in pursuing financial and capital account liberalization, they will also follow them in abandoning intermediate regimes. Compared to other developing countries, emerging markets both have more open capital accounts and a greater tendency to abandon intermediate regimes (relative openness to foreign investment being how the emerging-markets category is defined), consistent with this view.

\footnotetext{
${ }^{12}$ This difference is reinforced by developments in the last couple of years (see footnote 8 above).
} 
Not everyone will agree that the further relaxation of capital controls is inevitable or even probable. Financial globalization has been reversed before in response to economic and political turbulence. Since renewed turbulence cannot be ruled out, neither can reversals. That said, many observers will agree that financial development, as it proceeds, shifts the balance of costs and benefits between capital account restrictions and capital account liberalization, in part by creating new avenues for evading controls (thereby rendering their effective operation more costly) while dampening at least partially the volatility against which controls are intended to protect. In this view, there is little question that developing countries will eventually follow the developed world in the direction of more openness to capital flows, although there remains the question of how quickly.

Another interpretation is that the advanced countries have been faster to abandon soft pegs because they have been faster to develop alternatives. Europe's alternative is Economic and Monetary Union (EMU). One emerging market (Slovenia) is now a member of EMU and another (Slovakia) is about to join. There are monetary unions in the developing world, notably in the East Caribbean and West Africa. ${ }^{13}$ That said, most developing countries do not have an appealing monetary-union option to lure them away from intermediate regimes, although one day, perhaps, with further economic, financial and political development, they will.

But another alternative to a pegged exchange rate as an anchor for monetary policy is inflation targeting. A number of advanced countries and emerging markets have been able to move away from soft pegs by installing this alternative approach to the formulation and conduct of monetary policy that ensures not just price stability but also a

\footnotetext{
${ }^{13}$ See e.g. van Beek et al. (2000) and Masson and Patillo (2004).
} 
reasonably well behaved exchange rate as well. This argument is given further development below.

\section{Determinants of Exchange Rate Regime Choice}

This section inquires into the determinants of exchange rate regime choice. The point of departure for this analysis is the theory of optimum currency areas, which points to country size, openness and the asymmetry of shocks, among other variables, as shaping the choice between pegging and floating and - in the present context - between hard pegs, intermediate regimes, and floats. It follows a previous attempt by Bayoumi and Eichengreen (1997) to bring that theory to the data. To explore the availability of alternatives to soft pegs, it follows Eichengreen and Taylor (2004) by extending this framework to incorporate the prerequisites for inflation targeting.

The focus is on the variability of the exchange rate between a pair of countries (as implicit in much of the optimum-currency-area literature). The exchange rate arrangement is measured by the volatility of the nominal bilateral rate over (centered) five-year periods. ${ }^{14}$ The results of analyzing real rates are very similar, since price levels display inertia and most of the variability in real rates over periods of five years or less derives from the variability of nominal rates. In focusing on actual exchange rate variability as a measure of the regime, the analysis parallels Ghosh, Gulde and Wolff

\footnotetext{
${ }^{14}$ Centering becomes important when a measure of inflation targeting is added below, since this measure is year as well as country specific. But the results are robust to different ways of calculating period averages. Thus, I have estimated the same basic equations, as in columns 1-3, 5-7 and 10-12 of Table 4, with all the same conclusions. There is also the fact that for a number of year/country-pair observations bilateral exchange rate variability is zero. The obvious solution to this problem is estimating by Tobit. Again, doing so makes for no substantial difference in results.
} 
(2003). Insofar as actual variability is the most important single consideration in most de facto regime classifications, it is consistent with the analysis in Section 2 above.

The basic specification relates the variability of the exchange rate to two measures of asymmetric shocks: the difference or asymmetry of output shocks (measured as the standard deviation of the difference in the change in log-GDP between the two countries), and the similarity or dissimilarity of export structures (as measured by the sum of the absolute differences in the shares of agriculture, mineral and manufacturing trade in total merchandise trade). In addition I consider the importance of bilateral trade linkages (measured as exports to the partner country, scaled by GDP, and averaged over the two countries) and the transactions costs associated with having a relatively variable exchange rate (which are assumed to decline with country size, measured here by the log of the product of real GDP of the two countries, in dollars). ${ }^{15}$

There is close conformance between the predictions of the theory and the results for the full sample (column 1 of Table 4). Countries with more dissimilar output movements have more variable bilateral rates. Countries whose export structures are more dissimilar have more variable bilateral rates. Larger economies have more variable rates. Countries that trade more with one another, on the other hand, have less variable

\footnotetext{
${ }^{15}$ Note that the number of countries included is now smaller because information on some of these correlates is lacking (year 2006 is omitted for the same reason). The country sample is in the appendix. At the same time the number of observations is greater, owing to the focus on bilateral relationships. Data are from the International Monetary Fund's Direction of Trade and International Financial Statistics, Penn World Tables, Statistics Canada's World Trade Analyzer, the World Bank's World Development Indicators, and the OECD's Main Economic Indicators. Given the focus on bilateral relationships, it is worth addressing the question of whether the observations are independent of one another, as required for classical statistical inference. While it is true that changes in bilateral rates are not independent (the change between the dollar and euro and between the euro and yen, for example), the standard deviations of these rates - which is what are considered here - are still independent, insofar as covariances differ across country pairs.
} 
bilateral rates. ${ }^{16}$ These effects all carry over when the sample is split between advanced and emerging-market countries. All of them continue to hold when the sample is split between the periods before and after the Asia-Russia-LTCM crisis (compare Tables 5 and $6)^{17}$

The model can be stress tested by adding additional potential determinants of de facto exchange rate arrangements. Countries with better developed financial markets (as measured by the average across the two countries in the M2/GNP ratio) enjoy more stable exchange rates. Where money growth rates diverge across countries, bilateral rates are more variable. Importantly, when these additional determinants are added, none of the central variables in column 1 is altered, in terms of sign or significance.

An additional variable of particular interest is a measure of capital account openness. The results here are surprising, in that pairs of countries with relatively open capital account regimes appear to have less variable exchange rates, other things equal. This is contrary to the notion that capital mobility compels movement toward greater flexibility. But capital account openness is not always significant at conventional confidence levels. It also varies across subsamples: it is negative for advanced countries but mostly positive for emerging markets. ${ }^{18}$ For the advanced countries, capital account openness may be picking up aspects of financial development not fully captured by the other independent variables but conducive to financial and currency stability. It may also be picking up omitted political determinants of exchange rate variability, including the institutions of the European Union. In the 1980s these mandated the removal of capital

\footnotetext{
${ }^{16}$ These effects are statistically significant at standard confidence levels.

${ }^{17}$ That crisis having been a potential watershed in exchange rate arrangements.

${ }^{18}$ Similar findings are reported in Bayoumi and Eichengreen (1997), where the coefficient on this variable is shown to vary across subperiods.
} 
controls as part of the single market program while at the same time providing the EMS as a currency stabilization device; at the end of the 1990s they combined open capital markets with the euro - options that were not available to emerging economies. For the latter, there is more evidence of the tradeoff between capital account openness and exchange rate stability predicted by the bipolar view.

Another contrast arises is when the variability of the bilateral exchange rate against the dollar is included to measure the global (or regional) exchange rate regime. For the period 1983-97 there is evidence that pegging to the dollar was an effective way for countries to peg to one another. (To put it another way, it appears that limiting the variability of dollar exchange rates was an effective way of limiting the variability of bilateral rates among third countries.) This effect is more strongly evident among emerging markets than advanced countries. This will not surprise those aware of the historical tendency for Asian countries, in particular, to stabilize intra-regional exchange rates by the use of dollar pegs. After 1997 the results for emerging markets are basically unchanged (long live de facto dollar pegging). But the coefficient for the advanced countries switches sign: for this subsample, greater stability vis-à-vis one another now is associated with less stability vis-à-vis the dollar. This is the monetary-union effect: EMU member states have effectively eliminated exchange rate variability among themselves while at the same time, as a result of the greater size and relatively lesser openness to the outside world of their union, learning to tolerate larger dollar fluctuations. 


\section{Inflation Targeting as an Alternative to Exchange Rate Targeting}

One of the appeals of pegged exchange rates is thus that they provide an anchor and practical guide for monetary policy. Their corresponding limitation is that the anchor may not be well suited to the structure of the economy or the shocks to which it is subjected. Small countries are essentially forced to import the monetary policy stance of the larger country or countries to which they peg. Inflation targeting has emerged in recent years as an increasingly popular alternative. A stable price level (or a low rate of inflation) becomes the anchor for monetary policy. To implement this framework the central bank must be granted the independence and clear mandate to credibly commit to low inflation. It then issues an inflation forecast, explains how its policy settings map into the specified target, and provides an explanation for instances where the target is missed. ${ }^{19}$ These steps should help to anchor market expectations and provide a mechanism for political accountability. Thus, in addition to independence and a mandate for price stability, transparency is required for the credibility of this regime..$^{20}$

It is sometimes said that floating is not a monetary policy strategy; rather, it is the absence of a strategy. Thus, by providing a substitute strategy, inflation targeting should reduce the pressure to target the exchange rate. This suggests a positive relationship between inflation targeting and exchange rate variability as countries reduce their

\footnotetext{
${ }^{19}$ Formally, inflation targeting can be defined as a monetary policy operating strategy with four elements: an institutionalized commitment to price stability as the primary goal of monetary policy; mechanisms rendering the central bank accountable for attaining its monetary policy goals; the public announcement of targets for inflation; and a policy of communicating to the public and the markets the rationale for the decisions taken by the central bank. Institutionalizing the commitment to price stability lends credibility to that objective and gives the central bank the independence needed to pursue it. Mechanisms for accountability make this pursuit politically acceptable and impose costs on central banks that are incompetent or behave opportunistically. Announcing a target for inflation and articulating the basis for the central bank's decisions allows these mechanisms to operate.

${ }^{20}$ As credibility is gained, it becomes possible for the central bank to deviate from the inflation target temporarily as needed to damp short-run fluctuations in output and employment without undermining belief in its commitment to price stability. This then provides more policy flexibility than a simple exchange rate peg. Hence "flexible inflation targeting."
} 
reliance on pegs for the nominal-anchor function. Alternatively, one might argue that, in developing countries in particular, where exchange-rate-centered monetary policy strategies are likely to be fragile and lack credibility, adopting a more robust and credible alternative like inflation targeting may in fact reduce exchange rate volatility. Insofar as inflation targeting provides a credible anchor for expectations, investors have less reason to believe that current inflation is a leading indicator of future inflation. As expectations become regressive rather than extrapolative, speculation becomes stabilizing. Exchange rates should then settle down.

The fourth and fifth equations in Table 4—and the corresponding specifications for the country and period subsamples - add a dummy variable that equals unity when at least one of the central banks in a country pair is classified as an inflation targeter. Because inflation outcomes are likely to be affected by the behavior of the exchange rate- to put it another way, because countries do not opt for inflation targeting at random-I instrument inflation targeting using a measure of transparency (taken from Transparency International.) Policy transparency is an important dimension of a successful inflation targeting strategy, as noted above: it is important both for managing expectations and providing for political accountability. But not all countries are equally capable of implementing policy transparency; where transparency is integral to the functioning of social, economic and political institutions, an inflation targeting regime is more likely to be feasible. Such is the rationale for using transparency as an instrument for inflation targeting. For completeness, I report the results estimated both with and without the instrument. 
The contrast between advanced countries and emerging markets is striking. In Table 4, inflation targeting enters with a negative coefficient for the emerging markets, as if its stabilizing effect on expectations also stabilizes the exchange rate, although the coefficient loses its statistical significance when instrumental variables are used. That negative effect is driven by post-1997 experience (compare Tables 5 and 6). In Table 6, which focuses on the 1998-2005 period, the negative coefficient on the inflation targeting dummy is statistically significant at standard confidence levels even when instrumented. It is of course in the post-1997 period when most developing-country experience with inflation targeting is concentrated. That the coefficients for this subsample are therefore better defined makes sense.

\section{Conclusion}

The advanced countries have already abandoned the unstable middle. The results here suggest that growing popularity of inflation targeting may allow a growing number of emerging markets to follow them without exposing the converts to high levels of exchange rate volatility. 


\section{References}

Alesina, Alberto and Alexander Wager (2003), “Choosing (and Reneging on) Exchange Rate Regimes,” NBER Working Paper no.9809 (June).

Bayoumi, Tamim and Barry Eichengreen (1997), "Optimum Currency Areas and Exchange Rate Volatility: Theory and Evidence Compared,” in Benjamin J. Cohen (ed.), International Trade and Finance: New Frontiers for Research, Cambridge: Cambridge University Press, pp.184-215.

Bubula, Andrea and Inci Otker-Robe (2002), "The Evolution of Exchange Rate Regimes since 1990: Evidence from De Facto Policies,” IMF Working Paper no.02/155 (September).

Crockett, Andrew (1994), “Monetary Implications of Increased Capital Flows,” in Changing Capital Markets: Implications for Monetary Policy, Kansas City: Federal Reserve Bank of Kansas City.

Eichengreen, Barry (1994), International Monetary Arrangements for the $21^{\text {st }}$ Century, Washington, D.C.: The Brookings Institution.

Eichengreen, Barry (2007), “The Break-Up of the Euro Area,” NBER Working Paper no.13393 (September).

Eichengreen, Barry and Raul Razo-Garcia (2006), “The International Monetary System in the Last and Next 20 Years,” Economic Policy 47, pp.393-442.

Eichengreen, Barry and Alan Taylor (2004), “The Monetary Consequences of a Free Trade Area of the Americas," in Antoni Esevadeordal, Dani Rodrik, Alan Taylor and Andres Velasco (eds), Integrating the Americas: FTAA and Beyond, Cambridge, Mass.: David Rockefeller Center Series on Latin American Studies, Harvard University, pp.189226.

Ghosh, Atish, Anne-Marie Gulde, and Holger Wolf (2003), Exchange Rate Regimes: Choices and Consequences: Cambridge, Mass.: MIT Press.

Genberg, Hans and Alexander Swoboda (1987a), "Fixed Rates, Flexible Rates, or the Middle of the Road: A Reexamination of the Arguments in View of Recent Experience," in Robert Z. Aliber (ed), The Reconstruction of International Monetary Arrangements, London: Macmillan, pp.92-116.

Genberg, Hans and Alexander Swoboda (1987b), "Changes fixes ou flottants: les leçons de l'après-Bretton Woods," in Relations internationales, Politique économique et Méthodologie: Essais en l'honneur de Jacques l'Huillier, Geneva: Georg, pp.155-176. 
Levy-Yeyati, Eduardo and Federico Sturzenegger (2003), “To Float or to Fix: Evidence on the Impact of Exchange Rate Regimes on Growth,” American Economic Review 93, pp.1173-1193.

Levy-Yeyati, Eduardo and Federico Sturzenegger (2007), "Fear of Floating in Reverse: Exchange Rate Policy in the 2000s,” unpublished manuscript, Universidad Torcuato Di Tell and Harvard University.

Masson, Paul (2001), “Exchange Rate Regime Transitions,” Journal of Development Economics 64, pp.571-586.

Masson, Paul and Catherine Pattillo (2004), The Monetary Geography of Africa, Washington, D.C.: The Brookings Institution.

Reinhart, Carmen and Kenneth Rogoff (2004), "The Modern History of Exchange Rate Arrangements: A Reinterpretation,” Quarterly Journal of Economics 119, pp.1-48.

Shambaugh, Jay (2004), "Exchange Rate Regime Classification,” www.dartmouth.edu/ shambau/.

Swoboda, Alexander (1986), "Credibility and Viability in International Monetary Arrangements,” Finance and Development 23, pp.15-18.

Van Beek, Frits, Jose Roberto Rosales, Mayra Zermeno, Ruby Randall, and Jorge Shepherd (2000), “The East Caribbean Currency Union,” Occasional Paper no. 195, Washington, D.C.: IMF. 
Table 1. Evolution of Exchange Rate Regimes: Bubula/Otker-Robe Classification

(percentage of members in each category)

\begin{tabular}{|c|c|c|c|c|c|c|c|c|c|c|c|c|c|c|c|c|c|}
\hline & \multicolumn{17}{|c|}{ Shares } \\
\hline & 1990 & 1991 & 1992 & 1993 & 1994 & 1995 & 1996 & 1997 & 1998 & 1999 & 2000 & 2001 & 2002 & 2003 & 2004 & 2005 & 2006 \\
\hline \multicolumn{18}{|c|}{ All Countries } \\
\hline $\begin{array}{l}\text { Hard Pegs }{ }^{1} \\
\text { Soft Pegs }\end{array}$ & $\begin{array}{l}16.88 \\
67.53\end{array}$ & $\begin{array}{l}17.31 \\
64.74\end{array}$ & $\begin{array}{l}20.45 \\
55.68\end{array}$ & $\begin{array}{l}17.32 \\
56.98\end{array}$ & $\begin{array}{l}17.78 \\
55.00\end{array}$ & $\begin{array}{l}18.23 \\
56.91\end{array}$ & $\begin{array}{l}18.23 \\
56.91\end{array}$ & $\begin{array}{l}20.33 \\
51.10\end{array}$ & $\begin{array}{l}20.33 \\
46.70\end{array}$ & $\begin{array}{l}25.82 \\
39.56\end{array}$ & $\begin{array}{l}26.37 \\
40.11\end{array}$ & $\begin{array}{l}26.92 \\
37.91\end{array}$ & $\begin{array}{l}26.92 \\
38.46\end{array}$ & $\begin{array}{l}26.92 \\
37.91\end{array}$ & $\begin{array}{l}26.92 \\
39.56\end{array}$ & $\begin{array}{l}26.92 \\
43.96\end{array}$ & $\begin{array}{l}26.92 \\
45.60\end{array}$ \\
\hline Floating $^{3}$ & 15.58 & 17.95 & 23.86 & 25.70 & 27.22 & 24.86 & 24.86 & 28.57 & 32.97 & 34.62 & 33.52 & 35.16 & 34.62 & 35.16 & 33.52 & 29.12 & 27.47 \\
\hline Total & 100 & 100 & 100 & 100 & 100 & 100 & 100 & 100 & 100 & 100 & 100 & 100 & 100 & 100 & 100 & 100 & 100 \\
\hline Members & 154 & 156 & 176 & 179 & 180 & 181 & 181 & 182 & 182 & 182 & 182 & 182 & 182 & 182 & 182 & 182 & 182 \\
\hline \multicolumn{18}{|l|}{ Advanced } \\
\hline Hard Pegs ${ }^{1}$ & 4.35 & 4.35 & 8.33 & 8.33 & 8.33 & 8.33 & 8.33 & 8.33 & 8.33 & 50.00 & 50.00 & 54.17 & 54.17 & 54.17 & 54.17 & 54.17 & 54.17 \\
\hline Soft Pegs ${ }^{2}$ & 69.57 & 69.57 & 45.83 & 50.00 & 50.00 & 50.00 & 58.33 & 54.17 & 54.17 & 12.50 & 12.50 & 4.17 & 4.17 & 4.17 & 4.17 & 4.17 & 4.17 \\
\hline Floating $^{3}$ & 26.09 & 26.09 & 45.83 & 41.67 & 41.67 & 41.67 & 33.33 & 37.50 & 37.50 & 37.50 & 37.50 & 41.67 & 41.67 & 41.67 & 41.67 & 41.67 & 41.67 \\
\hline Total & 100 & 100 & 100 & 100 & 100 & 100 & 100 & 100 & 100 & 100 & 100 & 100 & 100 & 100 & 100 & 100 & 100 \\
\hline Members & 23 & 23 & 24 & 24 & 24 & 24 & 24 & 24 & 24 & 24 & 24 & 24 & 24 & 24 & 24 & 24 & 24 \\
\hline \multicolumn{18}{|c|}{ Emerging Markets } \\
\hline Hard Pegs ${ }^{1}$ & 6.67 & 10.00 & 9.68 & 9.38 & 9.38 & 9.38 & 9.38 & 12.50 & 12.50 & 12.50 & 15.63 & 12.50 & 12.50 & 12.50 & 12.50 & 12.50 & 12.50 \\
\hline Soft Pegs ${ }^{2}$ & 76.67 & 66.67 & 64.52 & 75.00 & 68.75 & 81.25 & 78.13 & 56.25 & 53.13 & 40.63 & 37.50 & 34.38 & 34.38 & 34.38 & 34.38 & 40.63 & 40.63 \\
\hline Floating $^{3}$ & 16.67 & 23.33 & 25.81 & 15.63 & 21.88 & 9.38 & 12.50 & 31.25 & 34.38 & 46.88 & 46.88 & 53.13 & 53.13 & 53.13 & 53.13 & 46.88 & 46.88 \\
\hline Total & 100 & 100 & 100 & 100 & 100 & 100 & 100 & 100 & 100 & 100 & 100 & 100 & 100 & 100 & 100 & 100 & 100 \\
\hline Members & 30 & 30 & 31 & 32 & 32 & 32 & 32 & 32 & 32 & 32 & 32 & 32 & 32 & 32 & 32 & 32 & 32 \\
\hline \multicolumn{18}{|c|}{ Other Developing } \\
\hline Hard Pegs $^{1}$ & 22.77 & 22.33 & 25.62 & 21.14 & 21.77 & 22.40 & 22.40 & 24.60 & 24.60 & 24.60 & 24.60 & 25.40 & 25.40 & 25.40 & 25.40 & 25.40 & 25.40 \\
\hline Soft Pegs ${ }^{2}$ & 64.36 & 63.11 & 55.37 & 53.66 & 52.42 & 52.00 & 51.20 & 49.21 & 43.65 & 44.44 & 46.03 & 45.24 & 46.03 & 45.24 & 47.62 & 52.38 & 54.76 \\
\hline Floating $^{3}$ & 12.87 & 14.56 & 19.01 & 25.20 & 25.81 & 25.60 & 26.40 & 26.19 & 31.75 & 30.95 & 29.37 & 29.37 & 28.57 & 29.37 & 26.98 & 22.22 & 19.84 \\
\hline Total & 100 & 100 & 100 & 100 & 100 & 100 & 100 & 100 & 100 & 100 & 100 & 100 & 100 & 100 & 100 & 100 & 100 \\
\hline Members & 101 & 103 & 121 & 123 & 124 & 125 & 125 & 126 & 126 & 126 & 126 & 126 & 126 & 126 & 126 & 126 & 126 \\
\hline
\end{tabular}

Notes:

${ }^{1}$ Includes arrangements with another currency as legal tender, currency union and currency board and monetary union/monetary association.

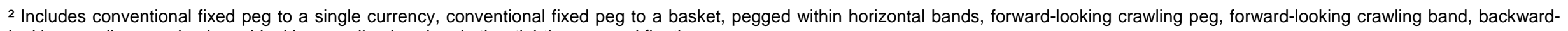
looking crawling peg, backward-looking crawling band and other tightly managed floating.

3 Includes managed floating with no predetermined path for the exchange rate and independently floating. 
Table 2. Evolution of Exchange Rate Regimes: Reinhart Rogoff Classification

(percentage of members in each category)

\begin{tabular}{|c|c|c|c|c|c|c|c|c|c|c|c|c|c|c|c|c|c|c|}
\hline \multicolumn{19}{|c|}{ Shares } \\
\hline & 1990 & 1991 & 1992 & 1993 & 1994 & 1995 & 1996 & 1997 & 1998 & 1999 & 2000 & 2001 & 2002 & 2003 & 2004 & 2005 & 2006 & 2007 \\
\hline \multicolumn{19}{|l|}{$\begin{array}{l}\text { ALL } \\
\text { COUNTRIES }\end{array}$} \\
\hline Hard Pegs ${ }^{1}$ & 22.31 & 20.77 & 20.46 & 20.00 & 21.32 & 22.14 & 22.63 & 23.91 & 23.40 & 31.92 & 31.92 & 33.33 & 33.33 & 33.57 & 33.57 & 32.86 & 32.86 & 33.57 \\
\hline Soft Pegs ${ }^{2}$ & 46.28 & 46.92 & 45.46 & 48.89 & 50.74 & 54.29 & 56.20 & 51.45 & 48.94 & 40.43 & 39.72 & 37.59 & 34.04 & 36.43 & 37.14 & 40.00 & 38.57 & 38.57 \\
\hline Floating $^{3}$ & 15.70 & 10.77 & 10.61 & 10.37 & 8.09 & 10.00 & 13.14 & 13.77 & 17.73 & 20.57 & 23.40 & 24.82 & 28.37 & 27.14 & 27.86 & 26.43 & 27.86 & 26.43 \\
\hline Freely Falling & 15.70 & 21.54 & 23.49 & 20.74 & 19.85 & 13.57 & 8.03 & 10.87 & 9.93 & 7.09 & 4.96 & 4.26 & 4.26 & 2.86 & 1.43 & 0.71 & 0.71 & 1.43 \\
\hline Total & 100 & 100 & 100 & 100 & 100 & 100 & 100 & 100 & 100 & 100 & 100 & 100 & 100 & 100 & 100 & 100 & 100 & 100 \\
\hline Members & 121 & 130 & 132 & 135 & 136 & 140 & 137 & 138 & 141 & 141 & 141 & 141 & 141 & 140 & 140 & 140 & 140 & 140 \\
\hline \multicolumn{19}{|l|}{ ADVANCED } \\
\hline Hard Pegs ${ }^{1}$ & 4.35 & 4.35 & 0.00 & 0.00 & 0.00 & 0.00 & 0.00 & 0.00 & 0.00 & 47.83 & 47.83 & 52.17 & 52.17 & 52.17 & 52.17 & 52.17 & 52.17 & 52.17 \\
\hline Soft Pegs ${ }^{2}$ & 73.91 & 73.91 & 56.52 & 65.22 & 65.22 & 65.22 & 65.22 & 65.22 & 65.22 & 21.74 & 17.39 & 13.04 & 8.70 & 8.70 & 13.04 & 13.04 & 13.04 & 13.04 \\
\hline Floating $^{3}$ & 21.74 & 21.74 & 34.78 & 34.78 & 34.78 & 34.78 & 34.78 & 34.78 & 34.78 & 30.44 & 34.78 & 34.78 & 39.13 & 39.13 & 34.78 & 34.78 & 34.78 & 34.78 \\
\hline Freely Falling & 0.00 & 0.00 & 8.70 & 0.00 & 0.00 & 0.00 & 0.00 & 0.00 & 0.00 & 0.00 & 0.00 & 0.00 & 0.00 & 0.00 & 0.00 & 0.00 & 0.00 & 0.00 \\
\hline Total & 100 & 100 & 100 & 100 & 100 & 100 & 100 & 100 & 100 & 100 & 100 & 100 & 100 & 100 & 100 & 100 & 100 & 100 \\
\hline Members & 23 & 23 & 23 & 23 & 23 & 23 & 23 & 23 & 23 & 23 & 23 & 23 & 23 & 23 & 23 & 23 & 23 & 23 \\
\hline \multicolumn{19}{|l|}{$\begin{array}{l}\text { EMERGING } \\
\text { MARKETS }\end{array}$} \\
\hline Hard Pegs ${ }^{1}$ & 10.00 & 10.00 & 9.68 & 10.00 & 10.00 & 9.38 & 9.38 & 12.50 & 15.63 & 15.63 & 18.75 & 18.75 & 15.63 & 15.63 & 15.63 & 12.50 & 12.50 & 12.50 \\
\hline Soft Pegs ${ }^{2}$ & 60.00 & 60.00 & 61.29 & 70.00 & 73.33 & 68.75 & 71.88 & 50.00 & 50.00 & 43.75 & 40.63 & 34.38 & 34.38 & 37.50 & 40.63 & 46.88 & 46.88 & 50.00 \\
\hline Floating $^{3}$ & 10.00 & 6.67 & 0.00 & 0.00 & 0.00 & 3.13 & 9.38 & 21.88 & 25.00 & 37.50 & 40.63 & 40.63 & 40.63 & 46.88 & 43.75 & 40.63 & 40.63 & 37.50 \\
\hline Freely Falling & 20.00 & 23.33 & 29.03 & 20.00 & 16.67 & 18.75 & 9.38 & 15.63 & 9.38 & 3.13 & 0.00 & 6.25 & 9.38 & 0.00 & 0.00 & 0.00 & 0.00 & 0.00 \\
\hline Total & 100 & 100 & 100 & 100 & 100 & 100 & 100 & 100 & 100 & 100 & 100 & 100 & 100 & 100 & 100 & 100 & 100 & 100 \\
\hline Members & 30 & 30 & 31 & 30 & 30 & 32 & 32 & 32 & 32 & 32 & 32 & 32 & 32 & 32 & 32 & 32 & 32 & 32 \\
\hline \multicolumn{19}{|l|}{$\begin{array}{l}\text { OTHER } \\
\text { DEVELOPING }\end{array}$} \\
\hline Hard Pegs ${ }^{1}$ & 33.82 & 29.87 & 30.77 & 29.27 & 31.33 & 32.94 & 33.74 & 34.52 & 32.56 & 33.72 & 32.56 & 33.72 & 34.88 & 35.29 & 35.29 & 35.29 & 35.29 & 36.47 \\
\hline Soft Pegs ${ }^{2}$ & 30.88 & 33.77 & 35.90 & 36.59 & 38.55 & 45.88 & 46.99 & 47.62 & 44.19 & 44.19 & 45.35 & 45.35 & 40.70 & 43.53 & 42.35 & 44.71 & 42.35 & 41.18 \\
\hline Floating $^{3}$ & 16.18 & 9.09 & 7.69 & 7.32 & 3.61 & 5.88 & 8.43 & 5.95 & 10.47 & 11.63 & 13.95 & 16.28 & 20.93 & 16.47 & 20.00 & 18.82 & 21.18 & 20.00 \\
\hline Freely Falling & 19.12 & 27.27 & 25.64 & 26.83 & 26.51 & 15.29 & 10.84 & 11.91 & 12.79 & 10.47 & 8.14 & 4.65 & 3.49 & 4.71 & 2.35 & 1.18 & 1.18 & 2.35 \\
\hline Total & 100 & 100 & 100 & 100 & 100 & 100 & 100 & 100 & 100 & 100 & 100 & 100 & 100 & 100 & 100 & 100 & 100 & 100 \\
\hline Members & 68 & 77 & 78 & 82 & 83 & 85 & 83 & 84 & 86 & 86 & 86 & 86 & 86 & 85 & 85 & 85 & 85 & 85 \\
\hline
\end{tabular}

Source: Author's estimates using Reinhart and Rogoff's exchange rate classification

1 / Includes arrangements with no separate legal tender, preannounced peg or currency boards, and preannounced horizontal band that is narrower than or equal to $+/-2 \%$

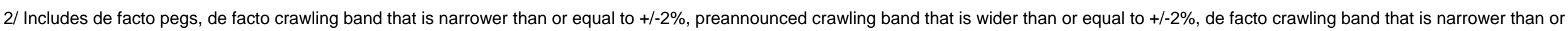

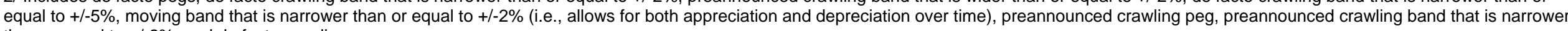
than or equal to $+/-2 \%$, and de facto crawling peg.

$3 /$ Includes managed floating and freely floating arrangements 
Table 3. Transition probability from period $t$ to period $t+1$

\begin{tabular}{|c|c|c|c|c|}
\hline Regime in Period $\mathrm{t}$ & Hard Peg & Intermediate & Floating & Total Observations \\
\hline \multicolumn{5}{|l|}{ All Countries } \\
\hline Hard Peg & 98.92 & 0.31 & 0.77 & 648 \\
\hline Intermediate & 1.08 & 91.74 & 7.18 & 1392 \\
\hline Floating & 0.37 & 10.12 & 89.51 & 820 \\
\hline Total & & & & 2860 \\
\hline Forecast 2025 & 31.47 & 38.97 & 29.56 & \\
\hline \multicolumn{5}{|c|}{ Advanced Countries } \\
\hline Hard Peg & 100.00 & 0.00 & 0.00 & 105 \\
\hline Intermediate & 8.46 & 86.15 & 5.38 & 130 \\
\hline Floating & 0.00 & 2.04 & 97.96 & 147 \\
\hline Total & & & & 382 \\
\hline Forecast 2025 & 62.35 & 5.11 & 32.55 & \\
\hline \multicolumn{5}{|c|}{ Emerging Market Countries } \\
\hline Hard Peg & 98.25 & 0.00 & 1.75 & 57 \\
\hline Intermediate & 0.00 & 88.45 & 11.55 & 277 \\
\hline Floating & 1.73 & 12.14 & 86.13 & 173 \\
\hline Total & & & & 507 \\
\hline Forecast 2025 & 20.38 & 41.56 & 38.14 & \\
\hline \multicolumn{5}{|c|}{ Other Developing Countries } \\
\hline Hard Peg & 98.77 & 0.41 & 0.82 & 486 \\
\hline Intermediate & 0.41 & 93.40 & 6.19 & 985 \\
\hline Floating & 0.00 & 11.80 & 88.20 & 500 \\
\hline Total & & & & 1971 \\
\hline Forecast 2025 & 23.60 & 49.35 & 27.05 & \\
\hline
\end{tabular}


Table 5: Determinants of Bilateral Exchange Rate Volatility, 1983-1997

\begin{tabular}{|c|c|c|c|c|c|c|c|c|c|c|c|c|c|c|c|}
\hline \multirow[b]{2}{*}{ Variables } & \multicolumn{5}{|c|}{ All Countries } & \multicolumn{5}{|c|}{ Advanced $^{\mathrm{a}}$} & \multicolumn{5}{|c|}{ Emerging Markets $^{\mathrm{b}}$} \\
\hline & [1] & [2] & [3] & [4] & {$[5]^{d}$} & [6] & [7] & [8] & [9] & {$[10]^{d}$} & [11] & [12] & [13] & [14] & {$[15]^{d}$} \\
\hline \multirow[t]{2}{*}{ Variability of output (SD(InYi-InYj)) } & 2.5722 & 1.5917 & 0.2315 & 0.2318 & -0.1014 & 0.2119 & -0.0397 & -0.0864 & -0.0814 & 0.1351 & 3.0765 & 1.8629 & 0.2098 & 0.2124 & 0.2659 \\
\hline & 0.0689 & 0.1009 & 0.0293 & 0.0294 & 0.1020 & 0.0427 & 0.1669 & 0.1539 & 0.1545 & 0.2422 & 0.1279 & 0.1430 & 0.0425 & 0.0425 & 0.1572 \\
\hline \multirow[t]{2}{*}{ Dissimilarity of exports } & 0.0051 & 0.0024 & 0.0003 & 0.0002 & 0.0013 & 0.0017 & 0.0003 & 0.0003 & 0.0003 & 0.0011 & 0.0039 & 0.0031 & 0.0006 & 0.0005 & 0.0005 \\
\hline & 0.0003 & 0.0004 & 0.0001 & 0.0001 & 0.0003 & 0.0001 & 0.0003 & 0.0002 & 0.0002 & 0.0004 & 0.0006 & 0.0006 & 0.0002 & 0.0002 & 0.0004 \\
\hline \multirow[t]{2}{*}{ Trade ratio } & -0.0239 & -0.0110 & 0.0034 & 0.0034 & -0.0002 & -0.0094 & -0.0070 & -0.0057 & -0.0057 & -0.0081 & -0.0192 & 0.0400 & -0.0368 & -0.0368 & -0.0744 \\
\hline & 0.0022 & 0.0040 & 0.0012 & 0.0012 & 0.0019 & 0.0007 & 0.0013 & 0.0012 & 0.0012 & 0.0012 & 0.0042 & 0.0239 & 0.0070 & 0.0070 & 0.0112 \\
\hline \multirow[t]{2}{*}{ Size of economy } & 0.0195 & -0.0032 & 0.0051 & 0.0051 & 0.0065 & 0.0147 & 0.0009 & 0.0078 & 0.0082 & 0.0361 & 0.0751 & -0.0007 & -0.0049 & -0.0053 & -0.0284 \\
\hline & 0.0027 & 0.0049 & 0.0014 & 0.0014 & 0.0036 & 0.0009 & 0.0033 & 0.0031 & 0.0032 & 0.0107 & 0.0070 & 0.0085 & 0.0025 & 0.0025 & 0.0076 \\
\hline \multirow[t]{2}{*}{ Capital account openness ${ }^{c}$} & & -0.0020 & 0.0046 & 0.0046 & 0.0017 & & -0.0031 & 0.0019 & 0.0017 & 0.0271 & & 0.0078 & 0.0082 & 0.0082 & 0.0022 \\
\hline & & 0.0017 & 0.0005 & 0.0005 & 0.0011 & & 0.0012 & 0.0013 & 0.0013 & 0.0078 & & 0.0033 & 0.0010 & 0.0010 & 0.0026 \\
\hline \multirow[t]{2}{*}{ Money ratio } & & -0.1676 & -0.0451 & -0.0451 & -0.0535 & & -0.0107 & -0.0428 & -0.0434 & 0.0074 & & -0.1832 & -0.0154 & -0.0158 & -0.0511 \\
\hline & & 0.0146 & 0.0042 & 0.0042 & 0.0080 & & 0.0096 & 0.0096 & 0.0097 & 0.0172 & & 0.0289 & 0.0085 & 0.0085 & 0.0158 \\
\hline \multirow[t]{2}{*}{ Openness } & & -0.0020 & 0.0002 & 0.0002 & -0.0008 & & -0.0007 & -0.0011 & -0.0011 & -0.0009 & & -0.0024 & 0.0000 & 0.0000 & -0.0011 \\
\hline & & 0.0002 & 0.0001 & 0.0001 & 0.0001 & & 0.0003 & 0.0003 & 0.0003 & 0.0006 & & 0.0003 & 0.0001 & 0.0001 & 0.0002 \\
\hline \multirow[t]{2}{*}{ Relative growth of money } & & 0.3737 & 0.0365 & 0.0365 & 0.0157 & & 0.0070 & -0.0058 & -0.0049 & 0.0541 & & 0.3582 & 0.0422 & 0.0422 & 0.0024 \\
\hline & & 0.0062 & 0.0021 & 0.0021 & 0.0149 & & 0.0243 & 0.0224 & 0.0226 & 0.0630 & & 0.0087 & 0.0030 & 0.0030 & 0.0208 \\
\hline \multirow[t]{2}{*}{ Variability of U.S. dollar exchange rate } & & & 1.7195 & 1.7196 & 1.7490 & & & 0.6199 & 0.6262 & 0.6035 & & & 1.6818 & 1.6826 & 1.8059 \\
\hline & & & 0.0062 & 0.0062 & 0.0182 & & & 0.0702 & 0.0719 & 0.2984 & & & 0.0084 & 0.0085 & 0.0266 \\
\hline \multirow[t]{2}{*}{ Inflation Targeting } & & & & 0.0008 & -0.0282 & & & & 0.0021 & 0.0529 & & & & 0.0069 & 0.0265 \\
\hline & & & & 0.0030 & 0.0093 & & & & 0.0051 & 0.0118 & & & & 0.0062 & 0.0124 \\
\hline \multirow[t]{2}{*}{ Constant } & -0.1774 & 0.3245 & -0.1082 & -0.1082 & -0.0437 & -0.1134 & 0.1634 & 0.0380 & 0.0330 & -0.6455 & -0.7352 & 0.3045 & 0.0079 & 0.0120 & 0.3697 \\
\hline & 0.0335 & 0.0609 & 0.0175 & 0.0175 & 0.0461 & 0.0114 & 0.0482 & 0.0467 & 0.0483 & 0.1970 & 0.0814 & 0.1058 & 0.0309 & 0.0311 & 0.0949 \\
\hline Observations & 15723 & 6944 & 6944 & 6944 & 1039 & 2759 & 444 & 444 & 444 & 84 & 5094 & 3711 & 3711 & 3711 & 507 \\
\hline $\mathbf{R}^{2}$ & 0.11 & 0.46 & 0.96 & 0.96 & 0.92 & 0.19 & 0.12 & 0.26 & 0.26 & 0.59 & 0.13 & 0.44 & 0.95 & 0.95 & 0.92 \\
\hline
\end{tabular}

${ }^{a}$ Advanced countries versus advanced countries only

${ }^{b}$ Emerging markets versus emerging markets

only

${ }^{\mathrm{c}}$ Brune's capital account openness index excluding exchange rate structure.

${ }^{\mathrm{d}}$ Estimated by IV.

Note: Standard errors are reported below the coefficients. The model controlling for inflation

targeting is estimated by IV. In the IV model, inflation targeting was instrumented using the index of corruption perceptions and the exogenous variables. 
Table 6: Determinants of Bilateral Exchange Rate Volatility, 1998-2005

\begin{tabular}{|c|c|c|c|c|c|c|c|c|c|c|c|c|c|c|c|}
\hline \multirow[b]{2}{*}{ Variables } & \multicolumn{5}{|c|}{ All Countries } & \multicolumn{5}{|c|}{ Advanced $^{\mathrm{a}}$} & \multicolumn{5}{|c|}{ Emerging Markets $^{\mathrm{b}}$} \\
\hline & [1] & [2] & [3] & [4] & {$[5]^{d}$} & [6] & [7] & [8] & [9] & {$[10]^{d}$} & [11] & [12] & [13] & [14] & {$[15]^{d}$} \\
\hline \multirow[t]{2}{*}{ Variability of output (SD(InYi-InYj)) } & 1.2351 & 1.0772 & 0.4268 & 0.3720 & 0.0412 & 0.0251 & -0.0197 & 0.0037 & 0.0164 & 0.0268 & 2.0793 & 2.0628 & 0.5230 & 0.4344 & 0.4556 \\
\hline & 0.0530 & 0.0612 & 0.0327 & 0.0330 & 0.0483 & 0.0381 & 0.0574 & 0.0546 & 0.0537 & 0.0546 & 0.1198 & 0.1250 & 0.0527 & 0.0538 & 0.0684 \\
\hline \multirow[t]{2}{*}{ Dissimilarity of exports } & 0.0025 & 0.0019 & 0.0014 & 0.0015 & 0.0021 & 0.0027 & 0.0022 & 0.0023 & 0.0021 & 0.0019 & 0.0014 & 0.0016 & 0.0008 & 0.0009 & 0.0009 \\
\hline & 0.0002 & 0.0002 & 0.0001 & 0.0001 & 0.0001 & 0.0001 & 0.0002 & 0.0002 & 0.0002 & 0.0002 & 0.0003 & 0.0003 & 0.0001 & 0.0001 & 0.0002 \\
\hline \multirow[t]{2}{*}{ Trade ratio } & -0.0101 & -0.0043 & 0.0001 & -0.0009 & -0.0066 & -0.0065 & -0.0026 & -0.0039 & -0.0040 & -0.0041 & -0.0091 & 0.0015 & -0.0026 & -0.0033 & -0.0030 \\
\hline & 0.0012 & 0.0016 & 0.0008 & 0.0008 & 0.0011 & 0.0006 & 0.0009 & 0.0009 & 0.0009 & 0.0009 & 0.0022 & 0.0039 & 0.0016 & 0.0016 & 0.0016 \\
\hline \multirow[t]{2}{*}{ Size of economy } & -0.0088 & -0.0053 & -0.0017 & -0.0003 & 0.0085 & 0.0197 & 0.0138 & 0.0081 & 0.0101 & 0.0117 & -0.0172 & -0.0289 & -0.0046 & 0.0006 & 0.0007 \\
\hline & 0.0017 & 0.0022 & 0.0012 & 0.0012 & 0.0016 & 0.0011 & 0.0021 & 0.0021 & 0.0021 & 0.0023 & 0.0043 & 0.0045 & 0.0019 & 0.0020 & 0.0031 \\
\hline \multirow[t]{2}{*}{ Capital account openness ${ }^{c}$} & & -0.0133 & -0.0059 & -0.0063 & -0.0093 & & -0.0101 & -0.0106 & -0.0098 & -0.0091 & & -0.0173 & 0.0028 & 0.0030 & 0.0026 \\
\hline & & 0.0008 & 0.0004 & 0.0004 & 0.0006 & & 0.0020 & 0.0019 & 0.0019 & 0.0020 & & 0.0016 & 0.0007 & 0.0007 & 0.0008 \\
\hline \multirow[t]{2}{*}{ Money ratio } & & -0.0655 & -0.0054 & -0.0028 & 0.0126 & & 0.0282 & 0.0289 & 0.0255 & 0.0227 & & -0.1291 & -0.0035 & 0.0024 & 0.0017 \\
\hline & & 0.0060 & 0.0032 & 0.0032 & 0.0043 & & 0.0054 & 0.0051 & 0.0051 & 0.0053 & & 0.0115 & 0.0048 & 0.0048 & 0.0057 \\
\hline \multirow[t]{2}{*}{ Openness } & & -0.0003 & 0.0000 & 0.0000 & 0.0000 & & -0.0001 & -0.0001 & 0.0000 & 0.0000 & & 0.0000 & 0.0000 & 0.0000 & 0.0000 \\
\hline & & 0.0001 & 0.0000 & 0.0000 & 0.0000 & & 0.0001 & 0.0001 & 0.0001 & 0.0001 & & 0.0001 & 0.0000 & 0.0000 & 0.0000 \\
\hline \multirow[t]{2}{*}{ Relative growth of money } & & 0.3231 & 0.0352 & 0.0309 & 0.0030 & & -0.0012 & 0.0013 & 0.0014 & 0.0016 & & 0.3627 & -0.0073 & -0.0132 & -0.0095 \\
\hline & & 0.0144 & 0.0080 & 0.0079 & 0.0104 & & 0.0129 & 0.0123 & 0.0120 & 0.0122 & & 0.0250 & 0.0107 & 0.0106 & 0.0115 \\
\hline \multirow[t]{2}{*}{ Variability of U.S. dollar exchange rate } & & & 1.4843 & 1.4835 & 1.4604 & & & -0.4854 & -0.5061 & -0.5230 & & & 1.5612 & 1.5630 & 1.5467 \\
\hline & & & 0.0123 & 0.0122 & 0.0160 & & & 0.0582 & 0.0573 & 0.0586 & & & 0.0141 & 0.0140 & 0.0150 \\
\hline \multirow[t]{2}{*}{ Inflation Targeting } & & & & -0.0199 & -0.1412 & & & & 0.0182 & 0.0331 & & & & -0.0204 & -0.0122 \\
\hline & & & & 0.0021 & 0.0483 & & & & 0.0036 & 0.0082 & & & & 0.0029 & 0.0092 \\
\hline \multirow[t]{2}{*}{ Constant } & 0.2049 & 0.2853 & -0.0015 & -0.0038 & -0.0107 & -0.2032 & -0.0506 & 0.0785 & 0.0391 & 0.0070 & 0.3157 & 0.5488 & 0.0085 & -0.0400 & -0.0438 \\
\hline & 0.0210 & 0.0275 & 0.0147 & 0.0146 & 0.0197 & 0.0145 & 0.0316 & 0.0338 & 0.0340 & 0.0379 & 0.0491 & 0.0555 & 0.0231 & 0.0239 & 0.0330 \\
\hline Observations & 8629 & 5656 & 5656 & 5656 & 5336 & 1405 & 650 & 650 & 650 & 650 & 2970 & 2436 & 2436 & 2436 & 2220 \\
\hline $\mathbf{R}^{2}$ & 0.11 & 0.26 & 0.79 & 0.80 & 0.67 & 0.35 & 0.37 & 0.43 & 0.45 & 0.44 & 0.11 & 0.29 & 0.88 & 0.88 & 0.88 \\
\hline
\end{tabular}

${ }^{a}$ Advanced countries versus advanced countries only

${ }^{b}$ Emerging markets versus emerging markets

only

${ }^{c}$ Brune's capital account openness index excluding exchange rate structure.

${ }^{\text {d }}$ Estimated by IV

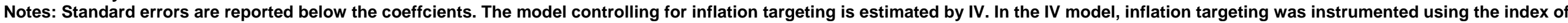
corruption perceptions and the exogenous variables. 
Table 7

\section{List of Countries Included in the Regressions}

\begin{tabular}{lll}
\hline Argentina & Iceland & Philippines \\
Australia & India & Poland \\
Austria & Indonesia & Portugal \\
Belgium & Ireland & Russian Federation \\
Brazil & Israel & Singapore \\
Bulgaria & Italy & South Africa \\
Canada & Japan & Spain \\
Chile & Jordan & Sri Lanka \\
China & Korea Rep. & Sweden \\
Colombia & Luxembourg & Switzerland \\
Czech Republic & Malaysia & Thailand \\
Denmark & Mexico & Turkey \\
Ecuador & Morocco & United Kingdom \\
Egypt Arab Rep. & Netherlands & United States \\
Finland & New Zealand & Venezuela RB \\
France & Nigeria & \\
Germany & Norway & \\
Greece & Pakistan & \\
Hong Kong China & Panama & \\
Hungary & Peru & \\
\hline
\end{tabular}

